Uşak Üniversitesi Sosyal Bilimler Dergisi

$2015,8 / 1$

\title{
Promoting Gender Equality in Educational Settings: The Role of Computer Supported Cooperative Learning
}

Istvan ZSIGMOND*

\begin{abstract}
New media makes possible new forms of collaboration and interaction in educational settings. Group-based instructional methods, as collaborative and cooperative learning can be mediated by specific computer-based applications and methods.

In this article arguments are presented for differentiating collaborative and cooperative learning methods on offline and computermediated environments as well. In comparison to CSCL (Computer Supported Collaborative Learning), there is a well-established need for further research into the areas of Computer Supported Cooperative learning (CSCpL), with special attention paid for its impact on peer relationships in general, and social inclusion or reducing gender differences in particular.
\end{abstract}

\section{New media - new possibilities}

The term "new media" has several meanings. We can refer to new media as the new kind of physical material on which data can be recorded, or the new support of information. More often, authors define new media as the possibility to access information without time and space constraints.

Accessing large amount of information from anywhere and anytime is a crucial characteristic of new media (connected ICT devices which makes possible storage and access large amount of information), which has consequences on almost every aspect of our life. The use of Information and Communication Technologies (ICT) is an everyday part of many people's lives, and has an impact on many aspects of society, like education, training and employment, the economic prosperity of individuals and countries, as well as media and information transfer, and leisure activity.

Beside the ease of access information with ICT devices, a second important characteristic of new media is the possibility to generate unregulated real-time content. This offers the possibility for content creators and users to interact with each other. Web 1.0 vastly expanded access to information, Web 2.0 allow users to meet and collaborate through online resources (social network sites, blogs, wikis, virtual communities). The importance of this second possibility of ICT based media was somehow

* Sr. Lect., Sapientia Hungarian University of Transylvania Human Sciences 
lately recognized, and the practical applications of user-driven content generation are still under development.

\section{New media in education}

The information-society metaphor made room for speculations about the necessity of educational reforms that will allow future citizens to survive in an information society.

Internet facilitated a content sharing culture that has been instrumental in the development of social learning. Increasing ease of access to information makes room for a student-centered learning approach. ICT can contribute to creating learning environments in which students can actively work on solving real problems encountered in daily life (Volman \& van Eck, 2001) Positive effects of ICT on learning also include cognitive processing, independent learning, critical thinking (Newman, Johnson, Webb, \& Cochrane, 1997), reflective thinking and teamwork. There is an early categorization of ICT applications from the perspective of improving education and learning (Bransford et al., 1999).

As about reflective thinking ICT tools can support it in at least two ways (Xie, Ke, \& Sharma, 2008). First, ease of teacher feedback foster reflective thinking (Rodgers, 2002; Spalding \& Wilson, 2002). Second, web2.0 technologies (like educational blogging) facilitates peer interaction (Redecker, Ala-Mutka, Bacigalupo, Ferrari, \& Punie, 2009). When providing information to each other or constructing explanations, students practice self-reflection (de Groot, Endedijk, Jaarsma, Simons, \& van Beukelen, 2014). The process of expressing ideas into words may be beneficial for students in terms of clarification of argument and writing skills. Through contributing their ideas and making their thought processes visible, the students are able to reflect on their cognitive processes and discuss with others what they do or do not know and understand. Writing for others gives student also an extra motivation to write carefully, stimulating metacognitive planning of written text (Vurdien, 2013; Zsigmond, 2013), and becoming aware of their thought processes, gaps in knowledge or lack of understanding (Webb, 1989).

We can conclude that learning environments created to enhance students working together and to encourage feedback between them stimulates reflective thinking (Chen, Chung, \& Wu, 2013; Scardamalia, Bereiter, \& Lamon, 1994), which is a central concept in metacognitive learning (Verpoorten, Westera, \& Specht, 2012). This leads us to new forms of learning and teaching in which students deal with knowledge in an active, self-directed and constructive way, leading to learning results that 
are more transferable to situations outside school as compared to traditional teaching methods (see, e.g. De Corte, et al., 2001; Bransford et al., 1999).

Furthermore, ICT can facilitate the development of critical thinking skills, for example through asynchronous discussion groups, allowing more time for reflection before responding (Guiller, Dumdell, \& Ross, 2008). Knowledge engagement challenges are key considerations for curriculums designed to use ICT for supporting and enhancing student learning. This challenge traditional instructional priorities that are largely based on textbooks (Fauville, Lantz-Andersson, \& Saljo, 2014).

However, in a recent review of research that has sought to integrate ICT and digital tools in education (Fauville et al., 2014), a key finding is that there is a limited number of research on how the rich variety of ICT tools and applications fit with implications for student learning. The review calls for further studies that will provide models of productive forms of teaching and learning that will make use of ICT resources.As about practial acpects, significant effort and investment has been put into maximizing the benefits of ICT within education and training. However, results show that the use of ICT in general merely showed characteristics of traditional approaches to learning (Smeets, 2005). According to an European Commission report, the majority of teachers do not use ICT for interactive educational activities. "ICT still has yet to revolutionize processes at schools" (EC, 2008, p8).

As some researchers suggest, educational technologists can foster a more expansive and empowered use of ICT in educational practice (Pelgrum, 2001; Selwyn, 2007). In a worldwide survey conducted by Pelgrum (2001) investigating the obstacles that educational practitioners perceive as impediments for realizing educational ICT objectives results show that even in very favorable conditions $40 \%$ of the practitioners complains that lack of hardware is an obstacle for proper use of ICT in education. As authors suggests, at least in these cases attitudes and knowledge should be changed for optimizing the use of the available equipment. Attitudes and beliefs of interested factors needs to be changed in order of effective use of ICT in education (Hew \& Brush, 2007). Teacher needs to be instructed about how to use ICT in a collaborative, interactive way.

\section{Collaborative and cooperative learning}

Educational ICT-assisted practices are often inspired by the principle of collaborative and cooperative learning, which has a whole tradition of research. These concepts are often used interchangeably (e.g. Ding, Bosker, \& Harskamp, 2011). As Resta \& Laferriere (2007) notes, there is no agreement on precisely what the differences between cooperative learning 
and collaborative learning are. However, as others argue (e.g. Lehtinen, Hakkarainen, Lipponen, Rahikainen, \& Muukkonen, 1999), there are differences between these two terms, based on the different roles and participation of individuals in group-learning activities (see table 1 for comparison).

Collaborative learning is a way of dealing with people where there is a sharing of authority and acceptance of responsibility among group members for the group actions. It is a personal philosophy, not just a classroom technique.

Cooperative learning can be regarded as a specific kind of collaborative learning (Prince, 2004). It is regarded as a structure of interaction which can be applied to any learning situation. This is referred as a structural approach of cooperative learning, with content-free series of steps, and proscribed behavior in each step.

A crucial requirement for a collaborative method to "become" cooperative is to organize the group work in a way to create positive interdependence of members (Johnson, Johnson, \& Holubec, 1998). A cooperative learning task is organized in a way that excludes withdrawal of group members from teamwork (social loafing); positive interdependence is needed to produce results. Each group member is responsible for group learning or activity results, and for his own learning too. This is accomplished by giving specific task responsibilities or roles, and by dividing group task between members in a way that group performance will depend member's performances. In contrast, in collaborative learning settings interpersonal interaction alone might be enough for achievement in learning groups.

Individual accountability is also required for a social learning situation to bee cooperative; that is each group member has to be accountable for his work and learning (Slavin, 1996). This is also facilitated by pre-defined, structured group interactions. Cooperative activities are therefore structurally more defined, rely on close-ended tasks with specific answers (see table 1). Structuring group interactions by applying the positive interdependence and individual accountability principles reduce social loafing. 
Table 1. Comparing collaborative and cooperative learning

\begin{tabular}{|c|c|c|c|}
\hline Aspects & Collaborative & Common & Cooperative \\
\hline Definition & $\begin{array}{c}\text { Learning in which learners } \\
\text { make a team to explore a } \\
\text { question or create a } \\
\text { meaningful project }\end{array}$ & $\begin{array}{l}\text { Social interaction for } \\
\text { educational purpose }\end{array}$ & $\begin{array}{c}\text { Specific kind of } \\
\text { collaborative learning. } \\
\text { Working face-to face, } \\
\text { learning as a team. } \\
\end{array}$ \\
\hline $\begin{array}{l}\text { Knowledge } \\
\text { acquisition } \\
\text { goal }\end{array}$ & $\begin{array}{c}\text { Foundational knowledge } \\
\text { (traditional view of } \\
\text { knowledge) }\end{array}$ & $\begin{array}{c}\text { Through social } \\
\text { interaction }\end{array}$ & $\begin{array}{c}\text { Higher-level, less } \\
\text { foundational knowledge }\end{array}$ \\
\hline Instructor role & $\begin{array}{c}\text { Instructor abdicates his } \\
\text { authority }\end{array}$ & $\begin{array}{c}\text { Coordinator or facilitator } \\
\text { of learning }\end{array}$ & $\begin{array}{l}\text { Center of authority in } \\
\text { the class }\end{array}$ \\
\hline $\begin{array}{l}\text { Nature of } \\
\text { tasks }\end{array}$ & $\begin{array}{l}\text { More open-ended, complex } \\
\text { tasks }\end{array}$ & $\begin{array}{l}\text { Require a specific task to } \\
\text { be completed by a group }\end{array}$ & $\begin{array}{c}\text { More close-ended tasks } \\
\text { with more specific } \\
\text { answers }\end{array}$ \\
\hline $\begin{array}{l}\text { Assigned } \\
\text { group roles }\end{array}$ & $\begin{array}{c}\text { Fewer assigned roles } \\
\text { (usually) }\end{array}$ & $\begin{array}{c}\text { Assign various group } \\
\text { roles }\end{array}$ & Assigned roles \\
\hline Member skills & $\begin{array}{c}\text { Group skills are necessary } \\
\text { (or will be acquired } \\
\text { implicitly) }\end{array}$ & $\begin{array}{l}\text { Student members are } \\
\text { required to possess } \\
\text { group skills }\end{array}$ & $\begin{array}{l}\text { Group skills can be the } \\
\text { instructional goal }\end{array}$ \\
\hline $\begin{array}{l}\text { Student } \\
\text { inclusion }\end{array}$ & Social loafing is possible & $\begin{array}{c}\text { Favor small-group active } \\
\text { student participation } \\
\text { over passive, lecture- } \\
\text { based teaching }\end{array}$ & Reduced social loafing \\
\hline $\begin{array}{l}\text { Activity } \\
\text { planning }\end{array}$ & $\begin{array}{c}\text { Defined loosely by question } \\
\text { to be answered, problem or } \\
\text { task to be resolved }\end{array}$ & $\begin{array}{c}\text { Each plan comes with a } \\
\text { framework upon which } \\
\text { the group's activity } \\
\text { resides }\end{array}$ & $\begin{array}{c}\text { Usually more } \\
\text { structurally defined }\end{array}$ \\
\hline $\begin{array}{l}\text { Type of } \\
\text { learning }\end{array}$ & & $\begin{array}{c}\text { Inherently supports a } \\
\text { discovery based } \\
\text { approach to learning }\end{array}$ & \\
\hline
\end{tabular}

Empirical results suggest that cooperation is more effective that competition (individual learning), promoting a range of positive learning effects, and also providing a natural environment to enhance interpersonal skills (Prince, 2004).

\section{Collaborative learning with ICT tools}

With the assistance of web2.0 tools, constructive-collaborative learning works well with the Internet. Looking to technology for its potential to create, support and enrich interpersonal contexts for learning gave birth to the concept and research area of CSCL: Computer Sup-ported Collaborative Learning (for reviews see Gress, Fior, Hadwin, \& Winne, 2010; Lehtinen et al., 1999). This can be defined as a model that unites learning theories with technological tools. According to this model, ICT can offer new possibilities for social intervention, can facilitate the creation of collaborative learning environments (communities), which should also be planned with 
real objectives, or integrated to real-world activities (Garcia-Valcarcel, Basilotta, \& Lopez, 2014).

Francescato et al. (2006) reports that computer-supported collaborative learning environments are as efficient as collaborative learning in face-to-face seminars in developing social presence and increasing professional competencies and self-efficacy. In a high-cited early study Alavi (1994) reports that test grades of students from a computer-supported collaborative learning group were significantly higher than those of the other group of students who participated in the experiment. Furthermore, there is research that looks at the benefits of using ICT for collaborative learning between classrooms (Moursund, Bielefeldt, \& Underwood, 1997).

CSCL could be more than a new tool or model: the idea of the Internet as a community where learners could come together, interact, and share knowledge was envisioned as a way to transform the field of education (Kozma \& Schank, 1998; Kramer, Walker, \& Brill, 2007). This idea led to elaboration of new teaching methodologies such as Internet and Communication Technology-assisted Collaborative Project-based Learning (ICTCPrjBL). Online student collaboration, the constructivist orientation of project-based learning (PrjBL) (ICTCPrjBL) are combined with the use of ICT in ICTCPrjBL (Moursund \& Smith, 2000).

\section{Computer Supported Cooperative Learning (CSCpL)}

In concordance with the terminological specifications mentioned, Computer Supported Cooperative Learning (CSCpL) would be ICT-assisted learning methods, based on principles of cooperative learning. As comparted to CSCL, relatively few researches address this subject directly, and authors usually doesn't make a clear difference between collaborative and cooperative learning settings (e.g. Korkmaz, 2012; Hew \& Cheung, 2008; Nam \& Zellner, 2011; Jones \& Issroff, 2005). Korkmaz (2012) developed a valid and reliable scale in order to determine students' attitudes towards cooperative learning in online environments. AbuSeileek (2012) reports that computer-based environment enable participants to blind their identities and reduce their anxiety, resulting in better post-test communication skills.

\section{Collaborative learning and social inclusion}

Cooperative techniques have positive impact on outcomes as positive peer relationships and helpfulness, although little studies address attitude changes or cross-group friendships outside of immediate classroom or to the entire racial or ethnic group (Paluck \& Green, 2008). Cooperative methods enhance ethic relations in desegregated classroom (Sharan, 1980). It 
is reported that in offline settings collaborative learning reduce gender and ethic differences, and is a determinant of openness to diversity (Cabrera et al., 2002).

There is research evidence concluding that there is genderstereotyped participation and communication patterns in CSCL, which could be overcome by addressing inclusiveness with collaborative methods (Prinsen, Volman, \& Terwel, 2007). Prinsen et al. (2007) argue for focusing research question on how classroom cultures can be promoted that support active participation of all students aimed at collaborative knowledge construction. However, as Volman \& van Eck (2001) concluded little attention has been paid to the differences between students in relation to CSCL. There is limited research data indicating that CSCL can eliminate gender differences (Tomai, Mebane, Rosa, \& Benedetti, 2014; Asterhan, Schwarz, \& Gil, 2012).

It can be expected that ICT-assisted collaborative and cooperative learning tasks to have the same effects on social inclusion and peer relationships as in case of offline methods. According to a report of the European Commission, ICT can be used as a tool for personalizing learning and for promoting equity in education and most countries in Europe encourage this (EC, 2011). In concordance with research evidence concerning benefic effects of offline cooperative learning methods on promoting equity and gender, it would be worthwhile to explore the effects of CSCpL methods on reducing gender stereotypes.

\section{References}

AbuSeileek, A. F. (2012). The effect of computer-assisted cooperative learning methods and group size on the EFL learners' achievement in communication skills. Computers \& Education, 58(1), 231-239. doi: 10.1016/j.compedu.2011.07.011

Alavi, M. (1994). Computer-mediated collaborative learning - an empiricalevaluation. MIS Quarterly, 18(2), 159-174. doi: 10.2307/249763

Asterhan, C. S. C., Schwarz, B. B., \& Gil, J. (2012). Small-group, computermediated argumentation in middle-school classrooms: The effects of gender and different types of online teacher guidance. British Journal Of Educational Psychology, 82(3), 375-397. doi: 10.1111/j.20448279.2011.02030.x

Bransford, J. D., Brown, A. L., Cocking, R. R., National Research Council, C. o. B., Social, S., \& Education, C. o. D. i. t. S. o. L. W. D. C. U. S. (1999). How people learn: Brain, mind, experience, and school. Washington, DC, US: National Academy Press. 
Cabrera, A. F., Crissman, J. L., Bernal, E. M., Nora, A., Terenzini, P. T., \& Pascarella, E. T. (2002). Collaborative learning: Its impact on college students' development and diversity. Journal Of College Student Development, 43(1), 20-34.

Chen, C. H., Chung, M. Y., \& Wu, W. C. V. (2013). The Effects of Faded Prompts and Feedback on College Students' Reflective Writing Skills. Asia-Pacific Education Researcher, 22(4), 571-583. doi: 10.1007/s40299-013-0059-z

De Corte, E., Verschaffel, L., \& Van de Ven, A. (2001). Improving text comprehension strategies in upper primary school children: A design experiment. British Journal Of Educational Psychology, 71, 531559.

de Groot, E., Endedijk, M. D., Jaarsma, A. D. C., Simons, P. R. J., \& van Beukelen, P. (2014). Critically reflective dialogues in learning communities of professionals. Studies in Continuing Education, 36(1), 15-37. doi: 10.1080/0158037x.2013.779240

Ding, N., Bosker, R. J., \& Harskamp, E. G. (2011). Exploring gender and gender pairing in the knowledge elaboration processes of students using computer-supported collaborative learning. Computers $\mathcal{E}$ Education, 56(2), 325-336. doi: 10.1016/j.compedu.2010.06.004

EC. (2008). The use of ICT to support innovation and lifelong learning for all - A report on progress. Brussels: EC.

EC. (2011). Key Data on Learning and Innovation through ICT at School in Europe 2011: Eurydice.

Fauville, G., Lantz-Andersson, A., \& Saljo, R. (2014). ICT tools in environmental education: reviewing two newcomers to schools. Environmental Education Research, 20(2), 248-283. doi: 10.1080/13504622.2013.775220

Francescato, D., Porcelli, R., Mebane, M., Cuddetta, M., Klobas, J., \& Renzi, P. (2006). Evaluation of the efficacy of collaborative learning in faceto-face and computer-supported university contexts. Computers In Human Behavior, 22(2), 163-176. doi: 10.1016/j.chb.2005.03.001

Garcia-Valcarcel, A., Basilotta, V., \& Lopez, C. (2014). ICT in Collaborative Learning in the Classrooms of Primary and Secondary Education. Comunicar(42), 65-74. doi: 10.3916/c42-2014-06

George, D. R., \& Dellasega, C. (2011). Use of social media in graduate-level medical humanities education: Two pilot studies from Penn State College of Medicine. Medical Teacher, 33(8), E429-E434. doi: 10.3109/0142159x.2011.586749 
Gress, C. L. Z., Fior, M., Hadwin, A. F., \& Winne, P. H. (2010). Measurement and assessment in computer-supported collaborative learning. Computers In Human Behavior, 26(5), 806-814. doi: 10.1016/j.chb.2007.05.012

Guiller, J., Dumdell, A., \& Ross, A. (2008). Peer interaction and critical thinking: Face-to-face or online discussion? Learning and Instruction, 18(2), 187-200. doi: 10.1016/j.learninstruc.2007.03.001

Hew, K. F., \& Brush, T. (2007). Integrating technology into K-12 teaching and learning: current knowledge gaps and recommendations for future research. EtrED-Educational Technology Research And Development, 55(3), 223-252. doi: 10.1007/s11423-006-9022-5

Hew, K. F., \& Cheung, W. S. (2008). Attracting student participation in asynchronous online discussions: A case study of peer facilitation. Computers E Education, 51(3), 1111-1124. doi: 10.1016/j.compedu.2007.11.002

Johnson, R. T., Johnson, D. W., \& Holubec, E. J. (1998). Cooperation in the Classroom. Boston: Allyn and Bacon.

Jones, A., \& Issroff, K. (2005). Learning technologies: Affective and social issues in computer-supported collaborative learning. Computers $\mathcal{E}$ Education, 44(4), 395-408. doi: 10.1016/j.compedu.2004.04.004

Korkmaz, Ö. (2012). A validity and reliability study of the Online Cooperative Learning Attitude Scale (OCLAS). Computers $\mathcal{E}$ Education, 59(4), 1162-1169. doi: http://dx.doi.org/10.1016/j.compedu.2012.05.021

Kramer, B. S., Walker, A., \& Brill, J. M. (2007). The Underutilization of Internet and Communication Technology-assisted Collaborative Project-Based Learning Among International Educators: A Delphi Study. Educational Technology Research \& Development, 55(5), 527-543.

Lehtinen, E., Hakkarainen, K., Lipponen, L., Rahikainen, M., \& Muukkonen, H. (1999). Computer supported collaborative learning: A review. . The J.H.G.I. Giesbers Reports on Education. Department of Educational Sciences. University on Nijmegen.

Nam, C. W., \& Zellner, R. D. (2011). The relative effects of positive interdependence and group processing on student achievement and attitude in online cooperative learning. Computers \& Education, 56(3), 680-688. doi: 10.1016/j.compedu.2010.10.010

Newman, D. R., Johnson, C., Webb, B., \& Cochrane, C. (1997). Evaluating the quality of learning in computer supported co-operative learning. Journal of the American Society for Information Science, 48(6), 484-495. doi: 10.1002/(SICI)1097-4571(199706)48:6<484::AID-ASI2>3.0.CO;2-Q 
Paluck, E. L., \& Green, D. P. (2008). Prejudice Reduction: What Works? A Review and Assessment of Research and Practice. Annual Review Of Psychology, 60(1), 339-367. doi: 10.1146/annurev.psych.60.110707.163607

Pelgrum, W. J. (2001). Obstacles to the integration of ICT in education: results from a worldwide educational assessment. Computers $\mathcal{E}$ Education, 37(2), 163-178. doi: 10.1016/s0360-1315(01)00045-8

Prince, M. (2004). Does active learning work? A review of the research. Journal of Engineering Education, 93(3), 223-231.

Prinsen, F. R., Volman, M. L. L., \& Terwel, J. (2007). Gender-related differences in computer-mediated communication and computersupported collaborative learning. Journal Of Computer Assisted Learning, 23(5), 393-409. doi: 10.1111/j.1365-2729.2007.00224.x

Redecker, C., Ala-Mutka, K., Bacigalupo, M., Ferrari, A., \& Punie, Y. (2009). Learning 2.0: The Impact of Wb2.0 Innovations on Education and Training in Europe JRC Scientific and Technical Reports. Luxemburg: Office for Official Publications of the European Communities.

Resta, P., \& Laferrière, T. (2007). Technology in Support of Collaborative Learning. Educational Psychology Review, 19(1), 65-83. doi: 10.1007/s10648-007-9042-7

Rodgers, C. R. (2002). Seeing student learning: Teacher change and the role of reflection. Harvard Educational Review, 72(2), 230-253.

Scardamalia, M., Bereiter, C., \& Lamon, M. (1994). The CSILE project: Trying to bring the classroom into World 3 McGilly, Kate (Ed). (1994). Classroom lessons: Integrating cognitive theory and classroom practice. (pp. 201 228). . xvi, 317 pp.SEE BOOK.

Selwyn, N. (2007). The use of computer technology in university teaching and learning: a critical perspective. Journal Of Computer Assisted Learning, 23(2), 83-94. doi: 10.1111/j.1365-2729.2006.00204.x

Sharan, S. (1980). COOPERATIVE LEARNING IN SMALL-GROUPS RECENT METHODS AND EFFECTS ON ACHIEVEMENT, ATTITUDES, AND ETHNIC-RELATIONS. Review Of Educational Research, 50(2), 241-271. doi: 10.3102/00346543050002241

Slavin, R. E. (1996). Research on cooperative learning and achievement: What we know, what we need to know. Contemporary Educational Psychology, 21(1), 43-69. doi: 10.1006/ceps.1996.0004

Smeets, E. (2005). Does ICT contribute to powerful learning environments in primary education? Computers \& Education, 44(3), 343-355. doi: 10.1016/j.compedu.2004.04.003 
Spalding, E., \& Wilson, A. (2002). Demystifying reflection: A study of pedagogical strategies that encourage reflective journal writing. Teachers College Record, 104(7), 1393-1421. doi: 10.1111/14679620.00208

Taradi, S. K., Taradi, M., Radic, K., \& Pokrajac, N. (2005). Blending problembased learning with Web technology positively impacts student learning outcomes in acid-base physiology. Advances in Physiology Education, 29(1), 35-39. doi: 10.1152/advan.00026.2004

Tomai, M., Mebane, M. E., Rosa, V., \& Benedetti, M. (2014). Can Computer Supported Collaborative Learning (CSCL) Promote Counterstereotypical Gender Communication Styles in Male and Female University Students? Procedia - Social and Behavioral Sciences, 116(0), 4384-4392. doi: http://dx.doi.org/10.1016/j.sbspro.2014.01.952

Verpoorten, D., Westera, W., \& Specht, M. (2012). Using reflection triggers while learning in an online course. British Journal Of Educational Technology, 43(6), 1030-1040. doi: 10.1111/j.1467-8535.2011.01257.x

Volman, M., \& van Eck, E. (2001). Gender equity and information technology in education: The second decade. Review Of Educational Research, 71(4), 613-634. doi: 10.3102/00346543071004613

Vurdien, R. (2013). Enhancing writing skills through blogging in an advanced English as a Foreign Language class in Spain. Computer Assisted Language Learning, 26(2), 126-143. doi: 10.1080/09588221.2011.639784

Webb, N. M. (1989). Peer interaction and learning in small groups. International Journal of Educational Research, 13(1), 21-39. doi: http://dx.doi.org/10.1016/0883-0355(89)90014-1

Xie, Y., Ke, F., \& Sharma, P. (2008). The effect of peer feedback for blogging on college students' reflective learning processes. The Internet and Higher Education, 11(1), 18-25. doi: 10.1016/j.iheduc.2007.11.001

Zsigmond, I. (2013). Blogging for Learning: A Case Study at Sapientia University. Paper presented at the EDULEARN13, Barcelona. 
